\title{
CORRECTION
}

Open Access

\section{Correction to: Development of a novel TLR8 agonist for cancer immunotherapy}

Yuxun Wang ${ }^{*}$, Heping Yang, Huanping Li, Shuda Zhao, Yikun Zeng, Panpan Zhang, Xiaogin Lin, Xiaoxiang Sun, Longsheng Wang, Guangliang Fu, Yaqiao Gao, Pei Wang and Daxin Gao

Correction to: Mol Biomed 1, 6 (2020)

https://doi.org/10.1186/s43556-020-00007-y

In article [1], the authors would like to change the Competing Interests statement to below:

\section{Competing interests}

YW, HY and DG have patent 10669252 (Benzazepine derivative, preparation method, pharmaceuticalcomposition and use thereof). YW, HY, HL, SZ, YZ, PZ, XL, XS, LW, GF, YG, PW and DG are the employees of Shanghai Denovo Pharmatech Co., Ltd.. This work was supported by Shanghai Denovo Pharmatech Co., Ltd..

Published online: 21 May 2021

\section{Reference}

1. Wang $Y$, Yang $H, L i H$, Zhao S, Zeng $Y$, Zhang $P$, et al. Development of a novel TLR8 agonist for cancer immunotherapy. Mol Biomed. 2020;1(1):6. https://doi.org/10.1186/s43556-020-00007-y.

* Correspondence: yuxun_wang@yahoo.com

Shanghai Denovo Pharmatech Co., Ltd., 576 Libing Road, Shanghai

Zhangjiang High-Tech Park, Pudong New District, Shanghai 201203, China

\section{Springer}

๑ The Author(s). 2021 Open Access This article is licensed under a Creative Commons Attribution 4.0 International License, which permits use, sharing, adaptation, distribution and reproduction in any medium or format, as long as you give appropriate credit to the original author(s) and the source, provide a link to the Creative Commons licence, and indicate if changes were made. The images or other third party material in this article are included in the article's Creative Commons licence, unless indicated otherwise in a credit line to the material. If material is not included in the article's Creative Commons licence and your intended use is not permitted by statutory regulation or exceeds the permitted use, you will need to obtain permission directly from the copyright holder. To view a copy of this licence, visit http://creativecommons.org/licenses/by/4.0/. 